\title{
THE FANTASY OF YOUTH IN PHILIP ROTH'S LATER NOVELS
}

\author{
GABRIELA GLĂVAN \\ West University of Timișoara, Romania
}

\begin{abstract}
I intend to explore Philip Roth's strategy of affirming youth as core value among his major themes revealing the experience of aging, illness and loss by revealing its particular framing in the novels of his later work. I shall analyze the contexts that connect youth to vitality and survival, revisiting some key moments in the long imaginary biographies of his notorious characters David Kepesh and Nathan Zuckerman. Although central in Roth's work, youth has been commonly investigated in connection to allegories that anchor the writer's oeuvre in a territory marked by nostalgia, loss, and a sense of impending vital exhaustion. My aim is to isolate this issue more clearly and focus on its specificity rather than its connectivity.
\end{abstract}

Keywords: youth, illness, sexuality, aging, female identity

As aging and illness gradually became central allegories in Philip Roth's later works, namely those novels revolving around the obsessions of an aging protagonist losing his vitality, health and creative drive, an inherent glorification of youth becomes noteworthy and predilect. This translates mainly into a Rothian dialect of sexual gratification, imagined as a means of defying death. If youth, as historical agent, is a reservoir of tragedy and destruction in American Pastoral (1997), it bears radically different meanings in the context of seduction, sexual dependence and dominance and ultimately failed romance, all central elements in Roth's later works. Novels such as The Dying Animal (2001), Exit Ghost (2007) and The Humbling (2009) recalibrate Roth's earlier views on the fractures and incongruence between older and younger age, as all three novels focus on sexual relationships. However, even when his interest regards other issues, such as pain and biological degradation - central themes in 
The Anatomy Lesson (1983) or Everyman (2006) - at least secondary reflections on the cardinal role of sex are present. Youth is one of Roth's recurrent allegories, transcending the turbulent biographies of his protagonists and articulating the writer's own symbolic system that distinguishes it as core value.

I intend to explore Roth's fidelity to his long-standing theme in his later novels, in order to reveal its connective and mirroring role. Although all focus on the misery of age-related biological decay, each presents a different version of the same mythology - an older man seeks validation and a chance to relive an age of potential and fervor while having an affair with a younger woman. David Kepesh, the literature professor and cultural media personality of The Dying Animal becomes obsessively involved with the young, seductive Consuela Castillo, who attends one of his courses, is invited to a party at his house and becomes his lover. The liaison rearranges Kepesh's illusions of power and control over his sexual and emotional urges. Not only does he become addicted to Consuela's physical charms, but he also experiences severe episodes of jealousy and torment as he realizes that she was simultaneously courted and desired by younger, more physically vigorous men. A true philosopher of the flesh (or, in Roth's terms, a professor of desire), Kepesh shares his cynical views on carnal affairs with his poet friend George O'Hearn, who mercilessly dissects Kepesh's passion for his decades-younger mistress: "This is the pathology in its purest form. ...Y You violated the law of aesthetic distance. You sentimentalized the aesthetic experience with this girl—you personalized it, you sentimentalized it, and you lost the sense of separation essential to your enjoyment.” (Roth, The Dying 99)

Indeed, "desire is figured as the revenge of death for Professor David Kepesh in Roth's novella, The Dying Animal (2001)" as Zoë Roth argues (96), and is directly fueled by the aging libertine's predilection for younger women, carefully selected at his traditional home party where they are invited for a rather open, known-by-all casting session. His public persona charm seems to have remained strong and active, confirming Kepesh's decision to have left behind his wife and son for a life of perpetual jouissance. His credo is honest and transparent, directly aimed at an exacerbated awareness of inescapable failure: "Because only when you fuck is everything that you dislike in life and everything by which you are defeated in life purely, if momentarily, revenged." (The Dying 69) In contrast with his former affairs, the one with Consuela implies a different dynamic of erotic dominance. Afraid of losing her to a younger man, Kepesh steps into the perilous territory of jealousy, despite George's warnings that he presents the symptoms of a man falling in love. Yet George's own biological decay casts serious doubts upon the validity of his beliefs, while at the same time reinforcing Kepesh's attachment to the supremacy of livelihood and youth. Like Amy Belette in Exit Ghost, or Millicent Kramer in Everyman, women of the same generation as Roth's gerontophobic 
protagonists are severely affected by illness and physical decay. They illustrate the very reality Roth's men try to escape and the mirroring effect they provide reflects the utter relevance the issue has in Roth's ethics. Moreover, the social acceptability of his inclination toward major age gaps in his romantic liaisons is reflected in the opposition of Carol and Asa Stapleford, two actors of the same age as Simon Axler, the burnt-out theater star who begins a sexual relationship with their daughter Pejeen in The Humbling.

In a dramatic reversal of the normative connection between aging and disease, The Dying Animal exposes the contamination of youth by the feared ravages of cancer. The gloriously beautiful Consuela, whose breasts endow her with the qualities of a work of art, resurfaces many years after she had left David Kepesh and announces to him that she has breast cancer. He bitterly concludes:

Consuela now knows the wounds of age. Getting old is unimaginable to anyone but the aging, but that is no longer so for Consuela. She no longer measures time like the young, marking backward to when you started. ... Now she measures time counting forward, counting time by the closeness of death. . . . Her sense of time is now the same as mine, speeded up and more forlorn even than mine. (The Dying 148)

As Aristie Trendel noted in his study concerning the fundaments of Kepesh's relationship to his student, Consuela, the pedagogic situation is "highly charged with erotic potential” (56). Kepesh feels like a Pygmalion shaping the young woman, giving her meaning and an identity, and he cannot accept her leaving him: "Me, who fired up her senses, who gave her stature, who was the catalyst to her emancipation" (The Dying 40). Moreover, he endows her with the attributes of a genuine work of art: "I had pronounced her a great work of art, with all the magical influence of a great work of art" (The Dying 37). The master/pupil relationship, as an exemplary form of power relationship persists, as her youth loses its essential authority once she became sick: "it seems only natural that when she finds herself suffering from breast cancer and at a loss, she turns to her teacher to finish her education.” (Trendel 60)

Consuela's youthful vitality is certified by the centrality, in the narrative, of her firm, large breasts and the abundance of her menstrual flow, turned into a source of eroticism and taboo-breaking lust by Kepesh's desire to imitate and surpass one of the woman's daring young lovers. Kepesh licks Consuela's menstrual blood "like a feeding infant," (The Dying 72) glorifying her vitality and, above all else, hoping to contaminate himself with the attributes of raw carnality and the physiological expression of hormonal health. The intensity of Kepesh's fixation with the plenitude of youth and its unparalleled sense of strength and control transcends the sexual dimension and the limits of his habitual seduction of former students. Consuela's decision to terminate the affair, following Kepesh's hesitation toward meeting her family and ultimately 
his refusal to attend her graduation party does not mark the actual end of the liaison. Her visit on the millennial New Year's Eve and her revelation that she had been diagnosed with breast cancer signal, on a higher level, the demise of Kepesh's fantasy of Consuela's primal vitality. As Trendel poignantly remarks, when Consuela's "youth is tarnished by the imminent mastectomy and the specter of death that the disease entails, Consuela becomes the mirror of the aging teacher's mortality.” (63) She no longer nourishes his need for contagion with youth, but tragically reminds him of the blind irrationality of disease, sparing none, young or old. The episode could be understood as a reversed contagion: Kepesh ceases to receive the woman's powerful flux of livelihood, since she is definitively burdened and scarred by the signs of irreversible decay. He becomes aware that he could no longer rely on her zest for life, and is faced with the unacceptable - youth is a deceiving veneer potentially harboring the same dangers as older age. The very center and essence of her work-of-art silhouette, her breasts, are scheduled for mutilation. Paradoxically, Consuela's life depended on a violent act meant to amputate the organs that symbolized her vital flourishing. Kepesh's description of her comeback and his tragic meditation on her fate reveal an unprecedented degree of emotional attachment for a male Roth character:

She's now in her thirties, thirty-two, and not less but more lovely, and the face, which seems somehow to have lengthened a bit, is far more womanly — and she's telling me, "I don't have any hair anymore. In October I was told that I've got cancer. I've got breast cancer.” I said, "This is awful, this is horrible, how do you feel, how does one deal with such a thing?" Her chemotherapy had begun in early November, and quickly she'd lost her hair. She said, "I have to tell you the story," and we sat down and I said, "Tell me everything." ... "And did you panic?” I asked her. "Did you panic my lovely friend?" I was so shaken, I was panicking. "Yes,” she said, "enormously." "At night?" "Yes, I was running around my apartment. I was completely crazy." I started to cry when I heard this, and we were embracing again, and I said, "Why didn't you call me?" ... And I was thinking, She is dying before my eyes, she too is now dying. Instability had merely to enter her cozy Cuban family life with the predictable death of a beloved old grandfather to set rapidly in motion a cascade of misfortune culminating in cancer. (The Dying 126-29)

In her study concerning some of Roth's later novels as illness narratives, specifically cancer narratives, Aimee Pozorski (2015) tackles the issue of women's cancers as a major emerging theme in contemporary American culture. Besides Consuela Castillo, who was diagnosed before the age of 32, Amy Bellette, of Exit Ghost, stands out as a character that is recalled from an earlier era in order to create a connection over time between the vibrant presence of 
herself as Lonoff's supposed mistress and her much older persona, defeated by one final, terminal tumor: "Like The Dying Animal, Roth's Exit Ghost connects the narrative arc of a once vibrant girl with death and old age through the figure of cancer. Exit Ghost marks the end of the Zuckerman novels and reintroduces Amy Bellette, who first appeared as a young and beautiful refugee in Roth's much earlier The Ghost Writer. (1979)" (Pozorski 114) Amy is the other ghost that accompanies Zuckerman's exit from the stage of Roth's alter-egos, as Consuela is the true dying animal and the tragic incarnation of mortality in the nexus of Roth's novel (114). Since her significantly older self is tightly connected to her once sparling vitality and Roth's intention to place these two biographical extremes in contrast is obvious, Amy's dramatic final act unfolds under the same mirroring effect that Roth had staged in other novels, such as American Pastoral or The Humbling.

The Humbling explores these contrasts in the form of an ironical chronicle of failed love, one reuniting, paradigmatically for Roth, an older man and a much younger woman, the daughter of his friends from his acting golden days. Simon Axler's affair with Pegeen Stapleford caricaturizes a parental tragicomedy in which the adult watches, in amazement, the younger character's mishaps and missteps. A former lesbian who had her heart broken after a failed romance with a woman who decided to undergo a sex change procedure, Pegeen still maintains the apparent freedom and carefree attitude of an adolescent rebelling against norms and rules. At 40, her affair with the sexagenarian Simon raises, in her opinion, one major concern - the reaction of her parents. Simon's failure to become her true partner lies in the younger woman's refusal to acknowledge her dependence on power relations and domination games. The age gap between partners may not be so steep as in other novels, but its significance is clear: the younger woman could be his daughter, even more so as he watched key scenes of her infancy - her parents' care for her in the first days of her life, her being breastfed by her mother - consolidating her position as the young one who, four decades later, has the last word in a relationship Simon reimagined as a blissful union that could make him a father. He recreated her as the best version she could be, buying her expensive clothes and giving her a taste of a more glamorous life with a still recognizable celebrity, but, once the affair had run its course, all she could, rather immaturely, utter was that she had made a mistake.

The central issue of Pegeen's relationship with Simon is, despite her protests, the significant age gap between them. Roth's acute interest in the aging phenomenon reaches its zenith in works such as The Anatomy Lesson (1983) and Everyman (2006), but it persists like a tragic mortality reminder to all his later protagonists. Pegeen's mother, who is approximately the same age as Simon, brutally clarifies the situation: 
What am I afraid of? I am afraid of the fact that he is growing older by the day. That's the way it works. You're sixty-five and then you're sixty-six and then you're sixty-seven, and so on. In a few years he'll be seventy. You'll be with a seventy-year-old man. And it won't stop there... After that he'll become a seventy-five year old man. It never stops. It goes on. He'll begin to have health problems such as the elderly have, and maybe things even worse, and you're going to be the person responsible for him. (Roth, The Humbling 75-76)

This line of raw arguments, however prosaic, is meant to scrutinize the fundamental divergence that lies at the basis of Axler and Pegeen's affair and expose its age-related nature. He depended on her youth, her social mobility and ability to care for others, as his desire to father her child actually proved. She was the one who declared herself unavailable for such roles, after enjoying the aesthetic, "Galatealike" (Safer 41) metamorphosis he prompted her to undergo. In a rather simplistic equation, "he feels revitalized by her, and he believes she has been revitalized by him." (41) Axler did not commit suicide because he had been abandoned, though. His final act was a theatrical one, by which he tried to reinsert himself, rather tragicomically, into an artistic order. The greatness he failed to achieve in life would hopefully be gained in one final grand gesture in the manner of a Chekhovian character.

As Patrick Hayes argues, the critics who connected the writer's stylistic weakness, as manifested in The Humbling, to a certain general weakening that the writer might have undergone "due to his age" (Sidelsly 2009; Harrison 2009), are, in a way, close to a variant of the truth. As he further notes, "The Humbling was the work of a writer whose powers were failing - after all, the failure of artistic powers is the explicit theme of Roth's late work.” (Hayes 154) This novel from 2009 chronicles a version of Roth's predilect scenario of waning vitality - an artist loses his artistic disposition, his ability to connect with his inner creative flow and seeks to find a replacement for the great loss he feels. Pegeen was aware of his dishonest trade, she knew the specific void she was invited to fill. Moreover, she sensed Axler's excessive effort to please her sexually when he invited another woman in their bed, in a bizarre threesome meant to give her once more a taste of her former lesbian life. Fearful of losing her, Axler showed his openness to any compromise, however ridiculous and falsely selfless. His yearning for youth instrumentalized a relationship intended to defy any form of instrumentalization.

Roth further explores the connection between aging, illness and loss of virility/sexual prowess in Exit Ghost, exposing the sad spectacle of a decreasing zest for life and the tragic demise of the ability to enjoy sex. Constantly signifying an inherent trait of one's ability to overcome a certain tragic condition, sex also quantifies, in Roth's ethos, one's ability to remain involved and desirable in the social circuit of seduction and carnal possession. Biological 
weakness deepens the sexual crises of Roth's senior protagonists, and this is vastly reflected in his later novels. Roth's final Zuckerman novel, Exit Ghost, although reloading the same pattern involving an older man and a younger woman, does not reinstate a scenario in which such a couple materializes. Zuckerman's desire for the rich, beautiful Jamie Logan is never released into a proper courtship, as Zuckerman is impotent and incontinent, and his seduction skills were restricted to the verbal domain. He projects all the erotic tension of his fantasy into and imagined two- character play in which he rewrites roles, confesses his erotic attraction to her and his physical limitations that prohibit any concrete initiative. Amy Bellete, who was once, long before, just as fiery and vital as Jamie Logan, seems to signal the unavoidable failure of all exuberance and initiative into old age, illness and ultimately, death. Jamie's magnetic presence is permanently shadowed by the unnamed warning that she would, too, succumb to the endless pain and degradation that aging inevitably implies. Youth is part of Roth's essential axiology, but not as an innocent fantasy, but rather as an ironical, nostalgic one.

The Zuckerman of Exit Ghost speaks for all of Roth's avatars of the aging man who mourns the loss of his biological excellence, manifested as a long string of sexual affairs: "And so I set out to minimize the loss [of youth] by struggling to pretend that desire had naturally abated, until I came in contact for barely an hour with a beautiful, privileged, intelligent, self-possessed, languidlooking thirty-year-old... and I experienced the bitter helplessness of a taunted old man dying to be whole again.” (Roth, Exit Ghost 67) A straight and honest confrontation with bitter reality is paramount for Roth's lucid, cynical protagonist. The moment of reckoning is not only a trademark of Roth's fiction, but an essential source of conflict that rearranges the meaning of the character's biography. In Everyman, this revelation is articulated through a series of separate moments, consisting of a string of episodes of unexpected and rather premature severe illness. The protagonist's craving for youth coincides with the awakening of a consciousness of his own fragile anatomy, which showed early signs of crisis once he had turned 40, as The Anatomy Lesson's Zuckerman confessed.

Everyman, much like the Medieval morality play, uncovers the strategies the man employs to escape the looming threat of death, and the revival of sexual desire is a primordial one. Declaring the death of marital desire, the middle-aged main character begins a long career of philandering with younger women:

It didn't begin until he was nearly fifty. The young women were everywhere - photographers' reps, secretaries, stylists, models, account executives. Lots of women, and you worked and traveled and had lunch together, and what was astonishing wasn't what happened the acquisition by a husband of 'someone else' - but that it took so 
long to happen, even after the passion had dwindled and disappeared from his marriage. (Roth, Everyman 108)

Torrid affairs followed, and their sole motivation stemmed from the man's growing awareness of his physical shortcomings. Periodical bouts of illness and hospitalization seemed to frame each liaison, most obviously with the Danish model Merete, who lost her spellbinding sexual aura once Everyman became convinced of her unidimensional flatness and lack of depth. Without naming it concretely, he points out the element that brought them together - their shared repulsion of growing old:

It was not long afterward that he discovered that Merete was something more than that little hole, or perhaps something less. He discovered her inability to think anything through without all her uncertainties intruding and skewing her thought. He discovered the true dimensions of her vanity and, though she was only in her twenties, her morbid fear of aging. (Everyman 124)

Anticipating the endless humiliation of old age, Everyman experienced rejection as he flirted with a young woman jogging on the boardwalk. He could not shift his attention from the young women parading their healthy glow before his eyes, while he was eager to meet someone, as long as she was not "one of the widows his age toward whom he felt no attraction.” (Everyman 101) Despite his long and solid experience as a seducer and a small initial success, the young woman seemed to start avoiding him:

He called out, "Miss, miss, I want to talk to you," and instead of shaking her head no and breezing by with a "Can’t now," as he fully imagined her doing, she turned and jogged back to where he was waiting. ... She never called. And when he took his walks he never saw her again. She must have decided to do her jogging along another stretch of the boardwalk, thereby thwarting his longing for the last great outburst of everything.” (Everyman 134)

The entire experience with young women seemed to have reached a dramatic climax once the man called his former "life", understood as vital flux and zest for life, a closed chapter: "My God, he thought, the man I once was! The life that surrounded me! The force that was mine! No 'otherness' to be felt anywhere! Once upon a time I was a full human being.” (Everyman 130) Later, he bitterly concluded: "Old age isn't a battle; old age is a massacre." (156) Following Alex Hobbs' argument, that Simon Axler is a "man trying desperately but ineffectually to fight against old age with sex," (50) the same can be concluded about all of Roth's aging protagonists of The Dying Animal, Everyman, and Exit Ghost. 
The need to be around youth maintains its double significance throughout Roth's later work - to regain a sense of one's own remaining vital resources and to persist in a state of grace, one that defies the unavoidable diminishing of physical strength, overall loss of appetite and the debilitating consequences of illness. His overarching elegy for youth (the "Paradise Lost" of American Pastoral) spans his entire later oeuvre and reveals the writer's intention to place young age, beauty and vitality at the core of his fictional edifice. Implicitly glorified as dynamic sexual agent, tragically deplored once lost and avidly sought in memory and remembrance, youth is one of Roth's supreme values.

\section{References}

Harrison, Kathryn. Rev. of The Humbling, by Philip Roth. New York Times Review of Books, November 11, 2009. Web.

Hayes, Patrick. Philip Roth, Fiction and Power. Oxford University Press. 2014. Print.

Hoobs, Alex, Aging Masculinity in the American Novel. Rowman and Littlefield. 2016. Print.

Pozorski, Aimee. "Confronting the "C" Word: Cancer and Death in Philip Roth's Fiction.” Philip Roth Studies. 11. 1 (Spring 2015): 105-123.

Roth Zoë. “Against Representation: Death, Desire, and Art in Philip Roth’s The Dying Animal.” Philip Roth Studies, 8. 1. (Spring 2012): 95-100. Print.

Roth, Philip, Everyman. Boston: Houghton Mifflin, 2006. Print. . Philip, Exit Ghost. Boston: Houghton Mifflin, 2007. Print. . The Humbling. Boston: Houghton Mifflin, 2009. Print.

Safer, Elaine B. "Philip Roth's The Humbling: Loneliness and Mortality in the Later Work.” Studies in American Jewish Literature, vol. 30, 2011. 40-46. Print.

Sidelsky, William. Rev. of The Humbling by Philip Roth, The Observer, October 25, 2009. Web.

Trendel, Aristie. “Master and Pupil in Philip Roth’s The Dying Animal.” Philip Roth Studies 3.1 (2007): 56-65. Print.

\section{BIONOTE}

Gabriela Glăvan teaches Comparative Literature at the Faculty of Letters, History and Theology, West University of Timișoara. She has published a book on the radical modernist authors of the Romanian interwar period, a book on Franz Kafka's best known short stories and numerous papers in relevant journals focusing on the imagination of childhood and premature death, on children's literature and post-communist nostalgia.

E-mail: gabrielleglavan@gmail.com 
